Bangladesh J. Zool. 49 (1): 47-56, 2021

ISSN: 0304-9027

eISSN: $2408-8455$

\title{
CULTURE OF THREE SEAWEED SPECIES IN COX'S BAZAR COAST, BANGLADESH
}

\author{
Md. Mohidul Islam, Jakia Hasan, Md Zulfikar Ali ${ }^{1}$ and Md. Enamul Hoq ${ }^{1^{*}}$ \\ Marine Fisheries \& Technology Station, BFRI, Cox's Bazar 4700, Bangladesh
}

\begin{abstract}
The experimental culture of 3 seaweed species, i.e. Hypnea musciformis, Enteromorpha intestinalis and Padina tetrastromatica in three locations of Cox's Bazar coast, Bangladesh using $4 \times 4 \mathrm{~m}$ horizontal coir rope net method were conducted during 2016 to 2018. Results showed that the biomass yield was highest from $H$. musciformis $\left(30.23 \pm 0.40 \mathrm{~kg} \mathrm{fw} \mathrm{m}^{-1}\right)$ and significantly differ from $E$. intestinalis $\left(24.50 \pm 0.08 \mathrm{~kg} \mathrm{fw} \mathrm{m}^{-1}\right)$ and P. tetrastromatica $\left(10.18 \pm 0.45 \mathrm{~kg} \mathrm{fw} \mathrm{m}^{-1}\right)$. The Daily Growth Rate (DGR) of $H$. musciformis (8.88\% day ${ }^{-1}$ ) was also higher than the DGR of E. intestinalis (6.55\% day $\left.{ }^{-1}\right)$ and P. tetrastromatica $\left(6.74 \%\right.$ day $\left.^{-1}\right)$. Saint Martin's Island showed higher biomass yield of seaweeds than Bakkhali and Inani due to favourable water quality. In context to physico-chemical parameters of seaweed farming, Cox's Bazar coast is suitable for seaweed cultivation, although more suitable culture areas and longer culture period yet to be identified. The findings of the present study suggest that the cultivation of $H$. musciformis is viable and coastal people can take up such activities as seasonal income generating activity in coastal water.
\end{abstract}

Key words: Hypnea musciformis, Enteromorpha intestinalis, Padina tetrastromatica

\section{INTRODUCTION}

Seaweeds known as important marine biota globally for its variety of commercial uses, like raw materials of bio-chemicals (agar, agarose, carrageenan etc.), food, drugs, bio-active compounds, feed and fertilizers. In Bangladesh seaweeds are naturally abundant in the littoral and sub-littoral zones of coastal and Sundarbans mangrove areas. Around 200 species belonging to 77 genera of seaweeds have so far been recorded from the Bangladesh coast by various studies and new species are included in the list (Aziz 2015, Islam et al. 2019, BFRI 2019, Mamun et al. 2020). These include 29-47 species of green seaweeds, 35-59 species of brown seaweeds, and 69-94 species of red seaweeds. At present, wild seaweeds of Cox's Bazar coast marketed to neighboring countries with some local consumption by tribal people. In recent time, culture of seaweed

*Author for corresponding: <hoqmenoman@gmail.com>, ${ }^{1}$ Bangladesh Fisheries Research Institute (BFRI), Mymensingh 2201, Bangladesh

(C)2021 Zoological Society of Bangladesh DOI: https://doi.org/10.3329/bjz.v49i1.53681 
along Cox's Bazar coast focusing a new dimension of prospect and possibility of seaweed mariculture in Bay of Bengal Bangladesh coast (Islam et al. 2017).

More than $80 \%$ of the seaweed production in 2015 was from Asia Pacific and the region is forecasted to witness the highest growth of more than $9 \%$ during 2015-2024 (GVR 2018). Ensuring food and nutrition security is a big challenge for over populated country like Bangladesh. Cultivable agricultural land decreases day by day for urbanization and industrial growth. In this context, alternative renewable food source is of prime importance. The extension of seaweed culture in the Bangladesh coast could have positive impacts on local poverty, family nutrition, ecosystem management and climate change mitigation. Govt. of Bangladesh already identified seaweed as a major mariculture component in its ongoing national development plans and targeting SDGs of UN. The present paper has addressed culture experiments of 3 seaweed species in different locations of the Cox's Bazar coast.

\section{MATERIALS AND METHODS}

Seaweed culture sites: Experimental culture sites of seaweeds were setup on intertidal zones of St. Martin's Island of Teknaf Upazilla(N20 37.043 , E092 $\left.{ }^{\circ} 19.715\right)$, Inani of Ukhia Upazilla (N2 $1^{\circ} 13.941$, E092 $\left.{ }^{\circ} 02.596\right)$ and Bakkhali river estuary under Sadar Upazilla (N2 $1^{\circ} 28.500$, E091 $\left.{ }^{\circ} 57.941\right)$ of Cox's Bazar district, located in the north-eastern coast of the Bay of Bengal. The St. Martin's Island characterized by sandy and rocky bottom and protected by the coral reef with slanting; where wave action is weak (Hossain et al. 2007). On the other hand, Inani beach has sandy bottom with large numbers of boulders, pebbles, broken shells etc. (Umamaheswara 1974). The Bakkhali river estuary site is mostly sandy to muddy bottom (Hena et al. 2013). The culture experiment was conducted for a period of 90 days in a season during January to April of 2016 to 2018.

Seaweed culture system: Natural fibered coir rope (made from coconut husk with $16 \mathrm{~mm}$ diameter) was used as culture material $(4 \mathrm{mx} 4 \mathrm{~m}$ sized horizontal square net). The mesh size of the coir rope nets was maintained at $20 \mathrm{~cm}$. in a bamboo frame. Four corners of the seaweeds culture nets were tied with bamboo pole or rocks and plastics floats were placed $50 \mathrm{~cm}$ above from the sea bottom.

Most abundant 3 types seaweed species like green seaweed Enteromorpha intestinalis, brown seaweed Padina tetrastromatica and red seaweed Hypnea musciformis were selected for culture experiment. Seeding was done by inserting the young fragments of E. intestinalis, $P$. tetrastromatica and $H$. musciformis with an average of $4 \pm 0.5 \mathrm{~kg}$ fw (fresh weight) and $5 \mathrm{~cm}$ length in the twists of the coir 
ropes with short length of string at a density of $35-40 \mathrm{seed} / \mathrm{m}^{2}$ for E. intestinalis and $H$. musciformis and $10-15 \mathrm{seed} / \mathrm{m}^{2}$ for $P$. tetrastromatica. During culture period, partial harvesting of seaweeds was done after 15-20 days culture period. At the end of 90 days experimental trials, mean biomass of seaweed was recorded for E. intestinalis and $H$. musciformis and expressed as wet weight of seaweed per unit culture area $\left(\mathrm{Kg} / \mathrm{m}^{2}\right)$. For $P$. tetrastromatica 60 days culture trial was maintained. Seaweed biomass was estimated with the following formula:

$$
Y=\left(W_{t}-W_{0}\right) / A
$$

Where: $Y=$ biomass production; $W_{t}=$ wet weight at day $t$;

$W_{0}=$ initial wet weight; $A=$ area of $4 \mathrm{~m}^{2}$ net.

During culture of seaweeds, daily growth rate (DGR) was calculated in every 15 days of culture period using a formula of Hung et al. (2009).

$$
\mathrm{DGR}=\left[\left(W_{t} / W_{0}\right)^{1 / t-1}\right] \times 100 \% \text { day }^{-1}
$$

Where: $W_{0}$ is the initial wet weight, $W_{t}$ is the final wet weight, and $t$ is days of culture.

Water quality parameters: Water depth, water temperature, salinity, dissolved oxygen, $\mathrm{pH}$, Alkalinity and water transparency of each culture sites were recorded at the time of partial harvest. Temperature was recorded by using a cellcious thermometer, salinity with a hand refractometer (Atago, Japan) and $\mathrm{pH}$ with a portable $\mathrm{pH}$ meter (HANNA Instruments USA). Dissolved oxygen in sea water was recorded immediately after sampling by method following APHA (2000) and water transparency was measured by using a Secchi disk $(30 \mathrm{~cm}$ in diameter).

Statistical analysis: All data were analyzed by using Predictive Analysis Software (PASW), Statistics 18 and Microsoft Office Excel 2013. One-way ANOVA was conducted following Tukey's HSD post-hoc for multiple comparisons. The level of significance considered was $\mathrm{p}<0.05$.

\section{RESULTS AND DISCUSSIONS}

Water quality parameters: The mean water quality parameters are presented in Table 1. The recorded water temperature, salinity, DO, alkalinity, transparency and water depth were high in St. Martin's Island with low $\mathrm{pH}$ among the 3 culture sites. 
Table 1. Water quality parameters of the seaweeds culture sites in Cox's Bazar coast

\begin{tabular}{lcccccc}
\hline $\begin{array}{c}\text { Experimental } \\
\text { sites }\end{array}$ & \multicolumn{6}{c}{ Water quality parameters } \\
\cline { 2 - 7 } & $\begin{array}{c}\text { Temperature } \\
\left({ }^{\circ} \mathbf{C}\right)\end{array}$ & $\begin{array}{c}\text { Salinity } \\
(\%)\end{array}$ & $\begin{array}{c}\text { DO } \\
(\mathbf{m g} / \mathbf{1})\end{array}$ & $\mathbf{p H}$ & $\begin{array}{c}\text { Transparency } \\
(\mathbf{c m})\end{array}$ & $\begin{array}{c}\text { Depth } \\
\text { (cm) }\end{array}$ \\
\hline $\begin{array}{l}\text { St. Martin's } \\
\text { Island }\end{array}$ & 25.8 & 31.0 & 8.3 & 7. & 90 & 140 \\
Inani & 23.8 & 29.5 & 7.6 & $\begin{array}{c}8 . \\
4\end{array}$ & 68.5 & 120 \\
Bakkhali & 24.5 & 24.5 & 7.2 & 7. & 60.2 & 105 \\
\hline
\end{tabular}

Daily growth rate (DGR): Among 3 culture sites, the daily growth rate of cultured red seaweed, $H$. musciformis attained maximum peak of $8.88 \pm 0.10 \%$ day $^{-1}$ at 15-day of culture period in St. Martin's Island. Whereas, lowest DGR of $0.41 \pm 0.06 \%$ day $^{-1}$ observed at linear also during 15-day culture period. Spatial variation in DGR portrayed a linier trend of increment from Inani to St. Martin's Island and found significantly higher in St. Martin's Island Inani followed by Bakkhali. DGR of $H$. musciformis was significantly different among the culture sites and sampling periods (Table 2).

Table 2. Daily growth rate (Mean \pm SD) of Hypnea musciformis in Cox's Bazar coast

\begin{tabular}{ccccc}
\hline $\begin{array}{c}\text { Duration } \\
\text { (day) }\end{array}$ & \multicolumn{2}{c}{ Daily growth rate (\% day ${ }^{-1}$ ) of seaweed } & Total \\
\cline { 2 - 4 } St. Martin & Bakkhali & Inani & \\
\hline 15 & $8.88 \pm 0.10$ & $1.71 \pm 0.05$ & $0.41 \pm 0.06$ & $11.00 \pm 0.20^{\mathrm{a}}$ \\
30 & $2.56 \pm 0.08$ & $1.87 \pm 0.04$ & $0.89 \pm 0.02$ & $5.32 \pm 0.09^{\mathrm{b}}$ \\
45 & $2.36 \pm 0.05$ & $2.47 \pm 0.02$ & $2.01 \pm 0.01$ & $6.84 \pm 0.06^{\mathrm{b}}$ \\
60 & $1.36 \pm 0.01$ & $2.97 \pm 0.02$ & $2.64 \pm 0.02$ & $6.97 \pm 0.05^{\mathrm{b}}$ \\
75 & $1.37 \pm 0.01$ & $2.03 \pm 0.13$ & $1.37 \pm 0.11$ & $4.77 \pm 0.30^{\mathrm{b}}$ \\
90 & $1.15 \pm 0.02$ & $1.12 \pm 0.13$ & $0.75 \pm 0.11$ & $3.02 \pm 0.20^{\mathrm{c}}$ \\
Total & $17.68 \pm 0.27^{\mathrm{a}}$ & $12.17 \pm 0.39 \mathrm{~b}$ & $8.07 \pm 0.33^{\mathrm{b}}$ & $40.92 \pm 0.94$ \\
\hline \multicolumn{5}{c}{ Different letters indicate significant variation $(p<0.05)}$.
\end{tabular}

In case of green seaweed, $E$. intestinalis, maximum daily growth rate of $6.55 \pm 0.15 \%$ day $^{-1}$ at 15 -day in St. Martin's Island and minimum daily growth rate of $0.65 \pm 0.03 \%$ day $^{-1}$ was observed at 90 -day in Inani. DGR of E. intestinalis was significantly different among the culture sites and sampling periods (Table 3). For brown seaweed, $P$. tetrastromatica, maximum daily growth rate of $6.74 \pm 0.01 \%$ day $^{-1}$ at $20^{\text {th }}$ day and minimum daily growth rate of $2.33 \pm 0.11 \%$ day $^{-1}$ was observed at $60^{\text {th }}$ day in St. Martin's Island. In Bakkhali site, the DGR value peaked $3.59 \pm 0.12 \%$ day $^{-1}$ at $20^{\text {th }}$ day and the lowest was $0.77 \pm 0.03 \%$ day $^{-}$ ${ }^{1}$ at $60^{\text {th }}$ day. In Inani, the DGR of seaweed was at a maximum $2.52 \pm 0.05 \%$ day ${ }^{1}$ at $20^{\text {th }}$ day and minimum $0.59 \pm 0.01 \%$ day $^{-1}$ was observed at $60^{\text {th }}$ day harvest (Table 4). 
Biomass yield: During 90 days culture period, mean biomass yield of $H$. musciformis found to be increased from Inani to St. Martin's Island, although there is no significant variation on seaweed yield appeared among 3 culture sites. In case of $E$. intestinalis, maximum biomass yield $\left(24.50 \pm 0.08 \mathrm{~kg} \mathrm{fw} \mathrm{m}^{-2}\right)$ obtained from St. Martin's Island and the lowest biomass $\left(13.84 \pm 1.06 \mathrm{~kg} \mathrm{fw} \mathrm{m}^{-2}\right)$ was from Inani. In contrast, during 60 days culture period, low biomass yielded in case of $P$. tetrastromatica compare to other seaweed species (Table 5).

Table 3. Daily growth rate (Mean \pm SD) of Enteromorpha intestinalis in Cox's Bazar coast

\begin{tabular}{ccccc}
\hline $\begin{array}{c}\text { Duration } \\
\text { (day) }\end{array}$ & $\begin{array}{c}\text { Daily growth rate (\% day } \\
\text { St. Martin }\end{array}$ & $\begin{array}{c}\text { Bakkhali } \\
\text { Ba seaweed } \\
\text { Inani }\end{array}$ & Total \\
\hline 15 & $6.55 \pm 0.15$ & $5.71 \pm 0.26$ & $4.71 \pm 0.30$ & $16.97 \pm 0.71^{\mathrm{a}}$ \\
30 & $4.18 \pm 0.05$ & $4.29 \pm 0.06$ & $3.21 \pm 0.31$ & $11.68 \pm 0.42^{\mathrm{a}}$ \\
45 & $3.25 \pm 0.04$ & $3.04 \pm 0.02$ & $2.34 \pm 0.02$ & $8.63 \pm 0.08^{\mathrm{b}}$ \\
60 & $1.85 \pm 0.01$ & $1.70 \pm 0.02$ & $0.97 \pm 0.05$ & $4.52 \pm 0.08^{\mathrm{c}}$ \\
75 & $1.48 \pm 0.03$ & $1.59 \pm 0.02$ & $0.78 \pm 0.03$ & $3.85 \pm 0.08^{\mathrm{c}}$ \\
90 & $1.10 \pm 0.05$ & $1.23 \pm 0.03$ & $0.65 \pm 0.03$ & $2.98 \pm 0.11^{\mathrm{c}}$ \\
Total & $18.41 \pm 0.33^{\mathrm{a}}$ & $17.56 \pm 0.41^{\mathrm{a}}$ & $12.66 \pm 0.74 \mathrm{~b}$ & $48.63 \pm 1.4$ \\
\hline \multicolumn{4}{l}{ Different letters indicate significant variation $(p<0.05)}$.
\end{tabular}

Table 4. Daily growth rate (Mean \pm SD) of Padina tetrastromatica in Cox's Bazar coast

\begin{tabular}{ccccc}
\hline $\begin{array}{c}\text { Duration } \\
\text { (day) }\end{array}$ & \multicolumn{2}{c}{ Daily growth rate (\% day } \\
St. $\mathbf{1}$ ) & of seartin & Bakkhali & Inani & Total \\
\hline 20 & $6.74 \pm 0.01$ & $3.59 \pm 0.12$ & $2.52 \pm 0.05$ & $12.85 \pm 0.18^{\mathrm{a}}$ \\
40 & $4.11 \pm 0.03$ & $1.75 \pm 0.2$ & $1.13 \pm 0.1$ & $6.99 \pm 0.33^{\mathrm{b}}$ \\
60 & $2.33 \pm 0.11$ & $0.77 \pm 0.03$ & $0.59 \pm 0.01$ & $3.69 \pm 0.14^{\mathrm{b}}$ \\
Total & $13.18 \pm 0.15^{\mathrm{a}}$ & $6.11 \pm 0.35^{\mathrm{b}}$ & $4.24 \pm 0.16^{\mathrm{b}}$ & $23.53 \pm 0.66$ \\
\hline
\end{tabular}

Different letters indicate significant variation $(p<0.05)$.

Table 5. Biomass yield $\left(\mathrm{Kg} \mathrm{m}^{-2}\right)$ of Hypnea musciformis, Enteromorpha intestinalis and Padina tetrastromatica in Cox's Bazar coast

\begin{tabular}{|c|c|c|c|}
\hline \multirow[t]{2}{*}{ Culture sites } & \multicolumn{3}{|c|}{ Biomass production(Mean \pm SD) $\mathrm{Kg} \mathrm{m}^{-2}$} \\
\hline & Hypnea musciformis & Enteromorpha intestinalis & $\begin{array}{c}\text { Padina } \\
\text { tetrastromatica }\end{array}$ \\
\hline St. Martin & $30.23 \pm 0.40^{a}$ & $24.50 \pm 0.08^{a}$ & $10.18 \pm 0.45$ \\
\hline Bakkhali & $21.40 \pm 0.09^{b}$ & $23.74 \pm 0.87^{a}$ & $8.34 \pm 0.25$ \\
\hline Inani & $14.82 \pm 0.16^{c}$ & $13.84 \pm 1.06^{b}$ & $5.14 \pm 0.54$ \\
\hline
\end{tabular}

Different letters indicate significant variation $(p<0.05)$.

\section{DISCUSSION}

In general, seaweeds are sedentary macrophytes growing mostly on rocks and other substrates in the inter-tidal and sub-tidal marine environment. In Bangladesh coast, seaweeds naturally grow during winter and remains up to pre-monsoon period. Most abundant seaweed Hypnea musciformis visible from Nobember to April in Cox's Bazar coast (BFRI 2019). In contrast, favorable time for culture of $H$. musciformis was observed from July to January with the peak 
during August to September in the Gulf of Mannar, Bay of Bengal coast, India (Reddy et al. 2014).

In comparison it was observed that the daily growth rates (DGR) of green seaweed, Enteromorpha intestinalis was higher than those of red seaweed, Hypnea musciformis and brown seaweed, Padina tetrastroin. The high salinity in St. Martin's Island site than other 2 sites resulted higher DGR for all seaweed species under culture. Similarly higher transparency and water depth also contributed to higher DGR in St. Martin's Island site. H. musciformis tolerates a wide range of water temperature, salinity and light intensity (Dawes et al. 1976). High water salinity in Florida coast was responsible for reduction in biomass yield of H. musciformis in summer (Durako and Dawes 1980), which is opposite to Cox's Bazar coast. In contrast to Hypnea spp., reports on culture of Enteromorpha and Padina are scarce. Culture of E. flexuosain in outdoor pool in Indian coast recorded 996 to $1350 \mathrm{~g}$ (fresh weight) $\mathrm{m}^{-2}$ yield in nylon thread (Mairh et al. 1986). In 25 days culture of Enteromorpha in the month of September they obtained faster growth of this seaweed, which was declined as seaweed reached maturity. It was observed that during mix culture of nonepiphytic fouling algae like Enteromorpha in low seedling density compete directly for space and nutrients with others (Hurtado et al. 2001). In our open water culture system sometimes $H$. musciformis was mixed with natural grown Enteromorpha spp., which was removed during partial harvesting and sometimes it was problem for good production. On the other hand, raft culture of $P$. boergesenii with coir rope in intertidal sea at Mandapam coast of India yielded 2,440 g (fresh weight) $\mathrm{m}^{-2}$ during 90 days culture period (Ganesan et al. 1999). $H$. musciformis is the widely available seaweed species in Bangladesh coast and the cultured yield of this species could be adding potential value for the production of industrial products, functional foods etc. A good number of pharmacological substances like lectin obtained from $H$. musciformis (Nagano et al. 2005), which act as antioxidants (Chakraborty et al. 2013) and has proven anti-microbial effects against human pathogens (Cordeiro et al. 2006).

The observed biomass yield during January to April culture period was high in case of $H$. musciformis, followed by $E$. intestinalis and $P$. tetrastromatica. The seasonal biomass yield in seaweed farming coincided with those of the natural populations of seaweeds in Bangladesh coast. When 3 species of seaweeds under study were abundant in the natural sea bed of Cox's Bazar coast, the cultured seaweed species also had maximum biomass yield. Similar findings were reported by Guist et al. (1982) in Florida coast of USA. One of the common problems detected at the seaweed culture site was drop in biomass yield during subsequent harvests, specially for Padina. This situation was noticed as result of 
loss of vigour, thallus aging and retardation of growth due to repeated harvest by clipping of apical meristems by Kaladharan et al. (1996) in case of Graclaria edulis and in case of G. acerosa by Rao and Subbaramaiah (1977). Hypnea has also apical meristems that were removed continuously during partial harvesting and leaving the older parts of the thallus behind. Subbaramaiah and Thomas (1990) observed that without planting with new frond in spite of repeated clipping for $H$. musciformis during 75 and 150 days of cultivation higher DGR and biomass yield was obtained. $H$. musciformis growth rate of $11.2 \%$ was much higher than other economically important seaweeds such as G. edulis (5\%) and G. acerosa (1.5\%), cultivated in the same area (Subbaramaiah and Banumathi 1992).

DGR and biomass yield of cultured seaweeds were highest in coir rope than polypropylene or nylon rope suggesting that coir rope performed better for supporting the seaweed growth (Ganesan et al. 2006). Coir ropes are fabricated locally from coconut husks and are readily available to farmers and the cost is cheaper than other synthetic ropes. During culture of seaweed, the water depth had a significant effect on the biomass yield of $H$. musciformis. In the present study, highest biomass yield was obtained at $50 \mathrm{~cm}$ depth at St. Martin's Island. These results agreed with the culture of $H$. musciformis in the Brazilian coast (Reis and Yoneshigue-Valentin 2000,) showed optimal growth was resulted at $40-50 \mathrm{~cm}$ depth. Moreover, growth rate of Hypnea was highest when water was supplemented with nitrogen and phosphorous (Guist et al. 1982) in indoor culture system. In this regard, higher biomass yield from higher seedling densities ( $30 \mathrm{~g} \mathrm{fw} \mathrm{m}^{-1}$ and above) and high DGR with little impact on duration of culture period with coir rope suggested possible cultivation of $H$. musciformis other than winter in Bangladesh.

In the present study, seaweed biomass yield was negatively correlated to water salinity while other water quality factors were not significantly correlated. The negative effect of strong seawater current on red algae was observed (Kain and Norton 1990) and storms had effect on $H$. musciformis biomass loss in natural beds at Brazilian coast (Caires et al. 2013). In addition it was observed that in culture of $H$. musciformis the seedlings on the top of horizontal net lost its colour possibly as a result of photoinhibition. Strong light intensity can reduce the growth of $H$. musciformis (Reis and Yoneshigue-Valentin 1998). In south east of India better results was observed when $H$. musciformis was cultured in wet season with low salinity (Ganesan et al. 2006). H. musciformis grew well in south east of India and northeastern Brazil with DGRs near 5\% day ${ }^{1}$ (Wallner et al. 1992, Ganesan et al. 2006). In St. Martin's Island, the DGR was recorded as $9 \%$ day $^{-1}$, which is higher than those reports. 
High carrageenan yield and for the production of more expensive bio-active compounds (e.g. lectin), or as biofilters in integrated multitrophic aquaculture the use $H$. musciformis has great potentials in Bangladesh coast. However, efforts should be strengthen to increase the production of this seaweed in our coast. The culture of seaweeds is measured as a low environmental risk or climate friendly. The experimental trials of 3 types of seaweeds using coir rope in Cox's Bazar coast is viable and fisher folk can take up such farming as a income generating activity and at the same time it reduces the fishing pressure in our coast. However, piloting seaweeds in the potential farming areas, mass cultivation technology and extended culture season are essential before seaweed farming to large scale. Despite the encouraging results observed in the present study for seaweed culture in the coast, these positive findings should be further investigated to test the culture of seaweeds in the saline pond, in indoor culture system and also the seasonality of culture.

Acknowledgement: This paper is outcomes of research on seaweeds conducted by Bangladesh Fisheries Research Institute under its core fund and DPP on "Research on seaweed culture in Bangladesh coast and seaweed product development".

\section{LITERATURE CITED}

AKHTAR, A., RAHMAN, M.F., KAMAL, A.H.M., KARIM, N.U. and HASSAN, M.L. 2020. Habitat structure and diversity patterns of seaweeds in the coastal waters of Saint Martin's Island, Bay of Bengal, Bangladesh. Regional Stu. Mar. Sci., 33: 100959

AZIZ, A. 2015.Seaweeds, the future revenues of Bangladesh coastal waters.p. 58. Proc. of the Marine Conservation and Blue Economy Symposium A.K.M.N. Alam, M.E. Hoq, M. Naser and K.A. Habib (eds.). 8 June 2015, Dhaka, Bangladesh. Save Our Sea. saveoursea.social/mcbes 15. 83 p.

BFRI (Bangladesh Fisheries Research Institute). 2019. Seaweeds of Bangladesh coast. Bangladesh Fisheries Research Institute. 152 p.

CAIRES, T.A., COSTA, I.O., JESUS, P.B., MATOS, M.R.B., PEREIRA-FILHO, G.H. and NUNES, J.M.C. 2013. Evaluation of the stocks of Hypnea musciformis (Rhodophyta: Gigartinales) on two beaches in Bahia, Brazil. Brazilian J. Oceanography 61: 65-71

CORDEIRO, A.R., GOMES, V.M., CARVALHO, A.F.U. and MELO, V.M.M. 2006.Effect of proteins from the red seaweed Hypnea musciformis (Wulfen) Lamouroux on the growth of human pathogen yeasts.Brazilian Archives of Biol. Technol.49: 915-921

DAWES, C.J., MOON, R., LACLAIRE, J. 1976. Photosynthetic responses of the red alga Hypnea musciformis (Wulfen) Lamouroux (Gigartinales).Bull. Mar. Sci.26: 467-473.

DURAKO, M.J., DAWES, C.J. 1980. A comparative seasonal study of two populations of Hypnea musciformisfrom the east and west coast of Florida. J. Growth and Chemistry. Mar. Biol. 59: 151-156. 
GANESAN, M., THIRUPPATHI, S. and JHA, B. 2006.Mariculture of Hypnea musciformis(Wulfen) Lamouroux in Southeast coast of India.Aquaculture256: 201-211.

GANESAN, M. SUBBA RAO, P.V. and O.P MAIRH, O.P. 1999. Culture of marine brown alga Padina boergesenii (Dictyotales, Phaeophyta) at Mandapam coast, southeast coast of India.Indian J. Mar. Sci.28: 461-463.

GUIST, J.R., DAWES, C.J. and CASTLE, J.R. 1982.Mariculture of the red seaweed, Hypnea musciformis. Aquaculture 28: 375-384.

GVRI (Grand View Research), 2018. Commercial Seaweed Market Size, Share \& Trends Analysis Report By Product (Red, Brown, Green), By Form (Liquid, Powdered, Flakes), By Application (Animal Feed, Human Consumption), and Segment Forecasts, 2018 - 2024. Report ID: 978-168038-995-1. 105 p.

CHAKRABORTY, K., JOSEPH, D. and PRAVEEN, N.K. 2013. Anti-oxidant activities and phenolic contents of three red seaweeds (Division, Rhodophyta) harvested from the Gulf of Mannar of Peninsular India. J. Food Sci. Technol.52, 1924-1935.

HENA, A.M.K., SIDIK, A.B.J., AYSHA, H. and AHASAN, F.T. 2013.Estuarine macrophytes at Bakkhali, Cox's Bazar, Bangladesh with reference to mangroves diversity.Chiang Mari. J. Sci.40(4): 556-563.

HOSSAIN, M.S., CHOWDHURY, S.R. and RASHED-UN-NABI, M. 2007.Resource mapping of Saint Martin's Island using satellite image and ground observations, J. For.Environ.,5: 23-36.

HUNG, L.D., HORI, K., NANG, H.Q., KHA, T. and HOA, L.T. 2009. Seasonal changes in growth rate, carrageenan yield and lectin content in the red algae Kappahycu salvarezii cultivated in Camranh Bay, Vietnam. J. Appl. Phycol., 21: 265-272.

HURTADO, A.Q., AGBAYANI, R.F., SANARES, R., TERESA, M., CASTRO MALlARE, R., 2001. The seasonality and economic feasibility in cultivating Kappaphycu salvarezii, in Panagaton Cays, Caluya, Antique, Philippines. Aquaculture 199: 195-210.

ISLAM, M.A., MAUYA, M.Z., RAFIQUZZAMAN, S.M., ISLAM, M.R. and LIAO, L.M. 2019. First report of the red algal Genus Chondria C. Agardh (Rhodomelaceae, Rhodophyta) for the marine flora of Bangladesh. Diversity, 11(6), 95; https://doi.org/10.3390/d11060095

ISLAM, M.M., KHAN, M.K.S., HASAN, J., MALLICK, D. and ENAMUL HOQ, M. 2017. Seaweed (Hypnea sp.) culture in selected locations of Cox's bazar coast of Bangladesh.Bangladesh $J$. Zool.,45(1): 37-48.

KAIN J.M. and NORTON T.A. 1990.Marine Ecology. In: Biology of the Red Algae (ed. by K.M. Cole \& R.G. Sheath), Cambridge University Press, New York, USA. 377-422.

KALADHARAN, P., VIJAYAKUMARAN, K., CHENNUBHOTLA, V.S.K., 1996. Optimization of certain physical parameters for the mariculture of Gracilaria edulis (Gmelin) Silva in Minicoy lagoon (Luccadive Archipelago).Aquaculture139, 265-270.

MAIRH, O.P., PANDEY, R.S. and TEWARI, A. 1986.Culture of Enteromorpha flexuosa (Wulf.) J.Ag. (C. Worophyceae) in Outdoor Pool. Indian J. Mar. Sci., 15: 212-218 
NAGANO, C.S., DEBRAY, H., NASCIMENTO, K.S., PINTO, V.P.T., CAVADA, B.S., SAKER-SAMPAIO, S., FARIAS, W.R.L., SAMPAIO, A.H. and CALVETE, J.J. 2005. HCA and HML isolated from the red marine algae Hypnea cervicornis and Hypnea musciformis define a novel lectin family. Protein Sci.14: 2167-2176

RAMA RAO, K. and SUBBARAMAIAH, K., 1977. Regeneration and regrowth of Gelidiella acerosa (Forssk) Feld et Hamel at Kilakkarai, southeastern shores of India. Indian J. Mar. Sci.6: 175177.

REDDY, C.R.K., SUBBA RAO, P.V., GANESAN, M., ESWARAN, K., ZAIDI, S.H. and MANTRI, V.A. 2014.The seaweed resources of India. In: A.T. Critchely, M. Ohno and D.B. Largo (eds.). World Seaweed Resources.ETI Information Services Ltd., Wokingham, Berkshire, UK.24 p.

SUBBARAMAIAH, K. and THOMAS, P.C. 1990. Raft cultivation of Gracilaria edulis (Gmel.) Silva.Proc. Indian Acad. Sci.100: 123-127.

UMAMAHESWARA RAO, M., 1974.On the cultivation of Gracilaria edulis in the near shore areas around Mandapam.Curr. Sci.43: 660-661.

(Manuscript received on 26 November, 2020 revised on 15 December, 2020) 